\title{
Microhabitat use by three species of egret (Pelecaniformes, Ardeidae) in southern Brazil
}

\author{
Pinto, DP. ${ }^{a,{ }^{*}}$, Chivittz, CC. ${ }^{a}$, Bergmann, FB. ${ }^{b}$ and Tozetti, AM. ${ }^{c}$ \\ ${ }^{a}$ Programa de Pós-graduação em Biologia de Ambientes Aquáticos Continentais, Laboratório de Ecologia de Vertebrados \\ Terrestres, Instituto de Ciências Biológicas, Universidade Federal do Rio Grande - FURG, Avenida Itália, km 8, \\ CEP 96201-900, Rio Grande, RS, Brasil. \\ ${ }^{b}$ Programa de Pós-graduação em Biodiversidade Animal, Centro de Ciências Naturais e Exatas, \\ Universidade Federal de Santa Maria - UFSM, Avenida Roraima, s/n ${ }^{\circ}$, CEP: 97105-900, Santa Maria, RS, Brasil. \\ ${ }^{c}$ Universidade do Vale do Rio dos Sinos, UNISINOS, Avenida Unisinos, 950, CEP 93022-000, São Leopoldo, RS, Brasil. \\ e-mail:deborapbio@hotmail.com
}

Received April 4, 2012 - Accepted November 27, 2012 - Distributed November 29, 2013

(With 1 figure)

\begin{abstract}
In the present study, we examined the role of different habitat components and their relationship with microhabitat use by three species of egret: Cocoi heron (Ardea cocoi), Great egret (Ardea alba), and Cattle egret (Bubulcus ibis), in wetlands of southern Brazil. Ardea alba and A. cocoi were not habitat-specific (e.g. vegetation cover and flooding level). Conversely, B. ibis was associated with drier microhabitats. Relative air humidity and air temperature were the main variables which correlated with the occurrence of these species and supported the plasticity of $B$. ibis and its predominance in drier habitats.
\end{abstract}

Keywords: Aquatic birds, marsh, habitat, Taim.

\section{Uso de micro-habitat por três espécies de garça (Pelecaniformes, Ardeidae) no sul do Brasil}

\section{Resumo}

No presente estudo foi avaliado o papel de diferentes componentes do habitat e sua relação quanto ao uso do microambiente por três espécies de Ardeidae: garça-moura (Ardea cocoi), garça-branca-grande (Ardea alba) e garça-vaqueira (Bubulcus ibis), em banhados do extremo sul brasileiro. Aparentemente, A. alba e A. cocoi não apresentaram especificidade a algum tipo de habitat (e.g. cobertura vegetal e nível de alagamento). Por outro lado $B$. ibis revelou associações a microambientes mais secos. A temperatura do ar e umidade relativa do ar foram as principais variáveis correlacionadas com a ocorrência dessas espécies, além disso, reforçou-se a plasticidade de $B$. ibis e sua predominância em ambientes secos.

Palavras chave: Aves aquáticas, banhados, habitat, Taim.

\section{Introduction}

Among the many bird species found in South-American wetlands, egrets (Ardeidae) are one of the most representative in abundance and frequency of occurrence and widely distributed in Brazil (Sick, 1997). Despite the considerable number of studies on their migration, and population dynamics (Antas, 1994; Nascimento and Schultz-Neto, 2000; Accordi, 2003), the use of micro habitats by egrets is still poorly understood (Yousefi et al., 2012). Despite the relative satisfactory level of knowledge about habitat use/selection for many species of birds (Block and Brennan, 1993), there is a lack of studies concerning the use of particular parts of the entire habitat (Poletto et al., 2004; Lopes and Marini, 2006; Yousefi et al., 2012). The availability of detailed infor- mation on microhabitat use is useful for development of ecological theories or models on species distribution, migrations and even for the ecological basis for habitat management (Hutto, 1985).

The southern region of Brazil comprises large areas of marshes (Waechter, 1985) and most of the country's richness of aquatic birds. Despite that, these habitats are under strong pressure from cattle ranching and agricultural activities (Guadagnin and Laidner, 1999), therefore studies in these areas are essential. The Brazilian flooded areas encompass nearly $50 \%$ of all wetlands in South America (Naranjo, 1995), most of them located in the Coastal Lowland and the Central Depression of Rio Grande do Sul (Maltchik et al., 2003). In these areas, marshes harbour many species of resident and/or migra- 
tory aquatic birds (Belton, 1994; Diegues, 2002). In general, ardeid birds exhibit a capacity to exploit a wide range of wet habitats (Gibbs, 2000; Oliveira, 2006). However, the migratory behaviour of Ardea alba (Linnaeus, 1758), indicates a tendency to move to particular regions due to the abiotic aspects (Sick, 1997; Nunes and Tomas, 2004). Probably many other local factors such as vegetation cover should influence the movements and at least the habitat use by $A$. alba and other egrets such as Ardea cocoi (Linnaeus, 1766), and Bubulcus ibis (Linnaeus, 1758), that are both nomad species. However these data are not available for subtemperate neotropical wetlands. Considering this, the present study aimed at examining biotic and abiotic environmental factors associated with microhabitat use by three species of egrets in subtemperate wetlands of southern Brazil.

\section{Material and Methods}

\subsection{Study site}

The study was carried out at the Taim Ecological Station (Taim ES), located in Rio Grande do Sul state $\left(32^{\circ} 50^{\prime} \mathrm{S}\right.$ and $52^{\circ} 26^{\prime} \mathrm{W}$ ) in the coastal region of southern Brazil. The area comprises lagoons connected to a system of marshes and temporary water bodies of an area of over 33.000 ha. The climate of the region is characterised as a transition between temperate and humid subtemperate climates, with annual average temperatures and rainfall of $17.8{ }^{\circ} \mathrm{C}$ and $1283.5 \mathrm{~mm}$, respectively (Maluf, 2000). During the study, the hottest months were March and April (average air temperature $=21.1^{\circ} \mathrm{C} \pm 1.1{ }^{\circ} \mathrm{C}$ ) and the coldest were July and August (average air temperature $=13.3{ }^{\circ} \mathrm{C} \pm 2.8{ }^{\circ} \mathrm{C}$ ). The climate data were obtained from the Meteorological Station of Rio Grande (\#83995), situated near the study site.

\subsection{Data collection}

Birds were directly counted (Bibby et al., 2000) between March and September 2011 during regular surveys (one day per week) between March and September 2011. A road that crosses the study site (BR 471) was used as a transection, and which was driven along by car at a speed below $20 \mathrm{~km} / \mathrm{h}$, and birds visually detected were recorded. The road is approximately $3 \mathrm{~m}$ above the surrounding terrain to prevent flooding. This location, in addition to the flat relief and predominance of low vegetation, allowed the observation of birds as close as approximately $600 \mathrm{~m}$ from the observer. The observations were carried out in the morning between 9:00 am and 12:00 am, when birds are very active, facilitating their detection. Ten kilometres of the road were monitored (from $32^{\circ} 20^{\prime} 49.74$ " S to $52^{\circ} 32^{\prime} 41.21^{\prime \prime} \mathrm{S}$ ). Both sides of the road were surveyed, each side by one observer. To reduce bias, the observers alternated the monitored side after each sampling. Flying birds were not included, counts were conducted with the naked eye with subsequent aid of binoculars (model 8x40 Bushnell) when necessary for species identification. Nomenclature followed Bencke et al. (2010) and CRBO (2011).

To examine microhabitat selection, records of available microhabitats and those used by birds were compared. The characterisation of microhabitats was carried out with standardised photos: (a) observer at the transection facing the water body, (b) camera set up horizontally at a fixed height of $1.5 \mathrm{~m}$ from the ground, (c) bird in the landscape in the centre of the image. To ensure that the habitat was adequately represented in the evaluation, images of birds that contained the sky or any other "nonhabitat" component in the photo (e.g. portion of the transect) were not included. All birds observed were photographed. Available microhabitats were quantified by using photographs taken every $2 \mathrm{~km}$ along the road. For the characterisation of used and available microhabitats, a grid with 25 squares was placed on each photo, and the type of ground cover was determined (adapted from Freitas et al., 2002; Bennetts et al., 2006). The predominant formation $(>50 \%)$ in each square was classified in one of the following categories: Tall vegetation on flooded substrate (TVFS), tall vegetation on dry substrate (TVDS), low vegetation on flooded substrate (LVFS), low vegetation on dry substrate (LVDS), floating vegetation (FV) and visible water surface (VWS). Also, each individual was recorded as on flooded, dry substrate or as roosting.

\subsection{Data analysis}

The use of different types of substrate (flooded, dry, and roosting) was analysed with the Kruskal Wallis test (Zar, 1999). The characterisation of the heterogeneity of the vegetation cover, as well as its association with each one of the egret species recorded, was carried out with a Principal Component Analysis (PCA), generated by the software MVSP, version 3.1 (Kovach, 1999). All records of $B$. ibis were obtained very distant from the transect, and adequate records of the habitat could not be obtained, as well as of the individuals in the image, in order to comply with methodological standards. Thus, the PCA was carried out only for A. alba and A. cocoi. The association of the presence of species in the study area with climatic variables was examined with the Spearmann correlation (Zar, 1999).

\section{Results}

During twenty-four field trips between March and September 2010, we obtained a total of 2001 records, 579 of A. alba, 624 of A. cocoi, and 798 of B. ibis (Table 1). Despite more records of $A$. alba $(\mathrm{n}=579)$ on dry substrate (average $=14.84$ records $/$ day \pm 17.00 ) than on flooded substrate (average $=8.16$ records/day \pm 10.42 ), the post hoc test for Kruskal Wallis was not significant. However, these substrates were more frequently used than perches (average $=0.48$ records/day $\pm 0.82 ; \mathrm{H}_{[2}$; $\left.{ }_{75]}=31.87 \mathrm{p}<0.01\right)$. The same was observed for $A$. coco $i$ $(\mathrm{n}=624)$, with a number of records on dry substrate (average $=14.60$ records $/$ day \pm 14.44$)$ not significantly dif- 


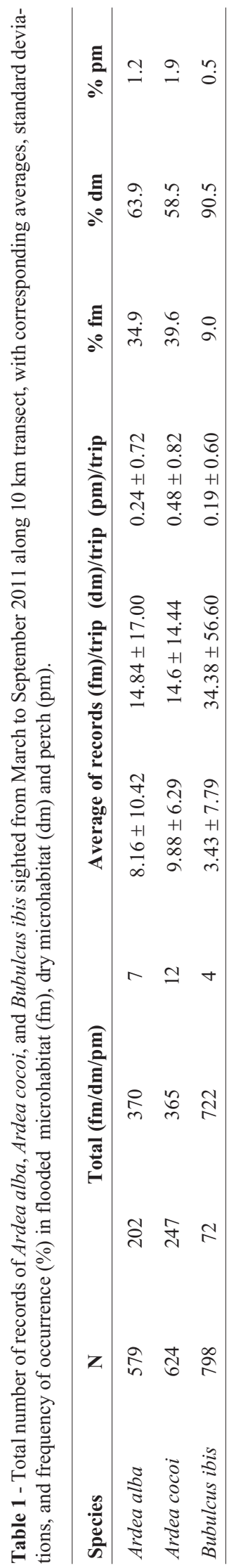

ferent than that on flooded substrate (average $=9.88$ records/day \pm 6.29 ), and both were used more frequently than perches (average $=0.48$ records $/$ day $\pm 0.82 ; \mathrm{H}$ $\left.{ }_{[2 ; 75]}=48.89 ; \mathrm{p}<0.01\right)$. For B. ibis $(\mathrm{n}=798)$, the number of records on dry microhabitats (average $=34.38$ records/day \pm 56.60$)$ was higher than those on flooded substrate (average $=3.43$ records/day \pm 7.78 ) or perches $\left(0.19\right.$ records/day $\pm 0.60 ; \mathrm{H}_{[2 ; 63]}=31.78 ; \mathrm{p}<0.001 ; \mathrm{Ta}-$ ble 1).

The number of individuals of $A$. alba recorded was negatively correlated with average air temperature $(\mathrm{r}=-0.44 ; \mathrm{p}=0.03)$ and accumulated monthly rainfall $(\mathrm{r}=-0.69 ; \mathrm{p}<0.001)$, but not with relative air humidity $(\mathrm{r}=0.19 ; \mathrm{p}=0.34)$ and wind speed $(\mathrm{r}=0.05 ; \mathrm{p}=0.81)$. For $A$. cocoi, a negative correlation was found only for the number of birds sighted and average air temperature $(\mathrm{r}=-0.43 ; \mathrm{p}=0.03)$, but not with accumulated rainfall $(\mathrm{r}=-0.20, \mathrm{p}=0.33)$, relative air humidity $(\mathrm{r}=0.11$; $\mathrm{p}=0.57)$, or wind speed $(\mathrm{r}=-0.19 ; \mathrm{p}=0.34)$. For B. ibis, no significant correlation was found between the number of birds sighted and any of the variables tested: average air temperature $(\mathrm{r}=0.14 ; \mathrm{p}=0.55)$, accumulated rainfall $(\mathrm{r}=0.42 ; \mathrm{p}=0.06)$, relative air humidity $(\mathrm{r}=0.26$; $\mathrm{p}=0.24)$ and wind speed $(\mathrm{r}=-0.25 ; \mathrm{p}=0.27)$.

We analysed 235 photo records, from which 131 were available microhabitats, 56 used microhabitats by A. alba and 48 by $A$. cocoi (this analysis was not carried out for $B$. ibis, see details in Material and Methods). The PCA revealed that despite the high availability of dry microhabitats, they were less frequently used than flooded ones, regardless of the type of vegetation cover (Tables 2 and 3). Both species examined were associated with microhabitats with presence of water body with floating vegetation, but also with large areas of visible water surface (Figure 1). The presence of low vegetation or shrubs seems to influence little in the selection of flooded microhabitats by egrets.

\section{Discussion}

Microhabitat use by $A$. alba and $A$. coco $i$ was similar. Both species were not selective regarding dry or flooded substrates, as also observed by other study (Gimenes and Anjos, 2011). However, these species are strongly biased toward flooded habitats (Motta-Junior, 2008; Carvalho, 2010; Gimenes and Anjos, 2011). It should be pointed out that in many studies on habitat use by egrets, little or no importance was given to analysing the use of the microhabitat (Moreno et al., 2004). Possible relationships between the pattern of vegetation cover, substrate types, flooding level and the selection of portions of the environment by studied egret species are virtually unknown (Dario, 2010). Our findings revealed that despite being present in wetlands (in a generic definition of the term "flooded habitats"), A. alba as well A. cocoi exploit substrates with or without water in a similar way, and rarely use perches to forage. On the other hand B. ibis exhibited preferences for dry microhabitats, possibly due to 
Table 2 - Autovalues and percentages of variance explained by the six principal components of the variance in the presence and type of vegetation, flooding associated with available and used microhabitats by two species of egret (Ardea alba and Ardea cocoi) in marshes of southern Brazil.

\begin{tabular}{lccccccc}
\hline & \multicolumn{7}{c}{ Axis } \\
\cline { 2 - 8 } & I & II & III & IV & V & VI \\
\hline Eigenvalues & 1.898 & 1.412 & 1.162 & 0.71 & 0.522 & 0.249 \\
Percentage & 31.886 & 23.718 & 19.514 & 11.932 & 8.775 & 4.175 \\
Accumulated percentage & 31.886 & 55.604 & 75.118 & 87.05 & 95.825 & 100 \\
\hline
\end{tabular}

Table 3 - Autovectors of the six principal components (axis 1 to 6) of the variation in the presence of shrubs, grass, trees, barren soil, shadow projected on the ground and air humidity associated with available and used microhabitat by two species of egret (Ardea alba and Ardea cocoi) in marshes of southern Brazil. The most important variables in the first axis are in bold. TVFS $=$ Tall vegetation on flooded substrate, TVDS $=$ Tall vegetation on dry substrate, LVDS $=$ Low vegetation on dry substrate, $\mathrm{LVFS}=$ Low vegetation on flooded substrate, FV = Floating vegetation, VWS = Visible water surface.

\begin{tabular}{lcccccc}
\hline & Axis 1 & Axis 2 & Axis 3 & Axis 4 & Axis 5 & Axis 6 \\
\hline TVFS & -0.266 & -0.048 & 0.183 & -0.598 & 0.520 & 0.515 \\
TVDS & 0.631 & -0.244 & 0.592 & 0.201 & -0.059 & 0.385 \\
LVFS & -0.134 & 0.077 & 0.07 & -0.436 & -0.845 & 0.260 \\
LVDS & 0.478 & 0.207 & -0.716 & -0.018 & 0.035 & 0.464 \\
FV & -0.425 & -0.646 & -0.228 & 0.423 & -0.106 & 0.399 \\
\hline
\end{tabular}

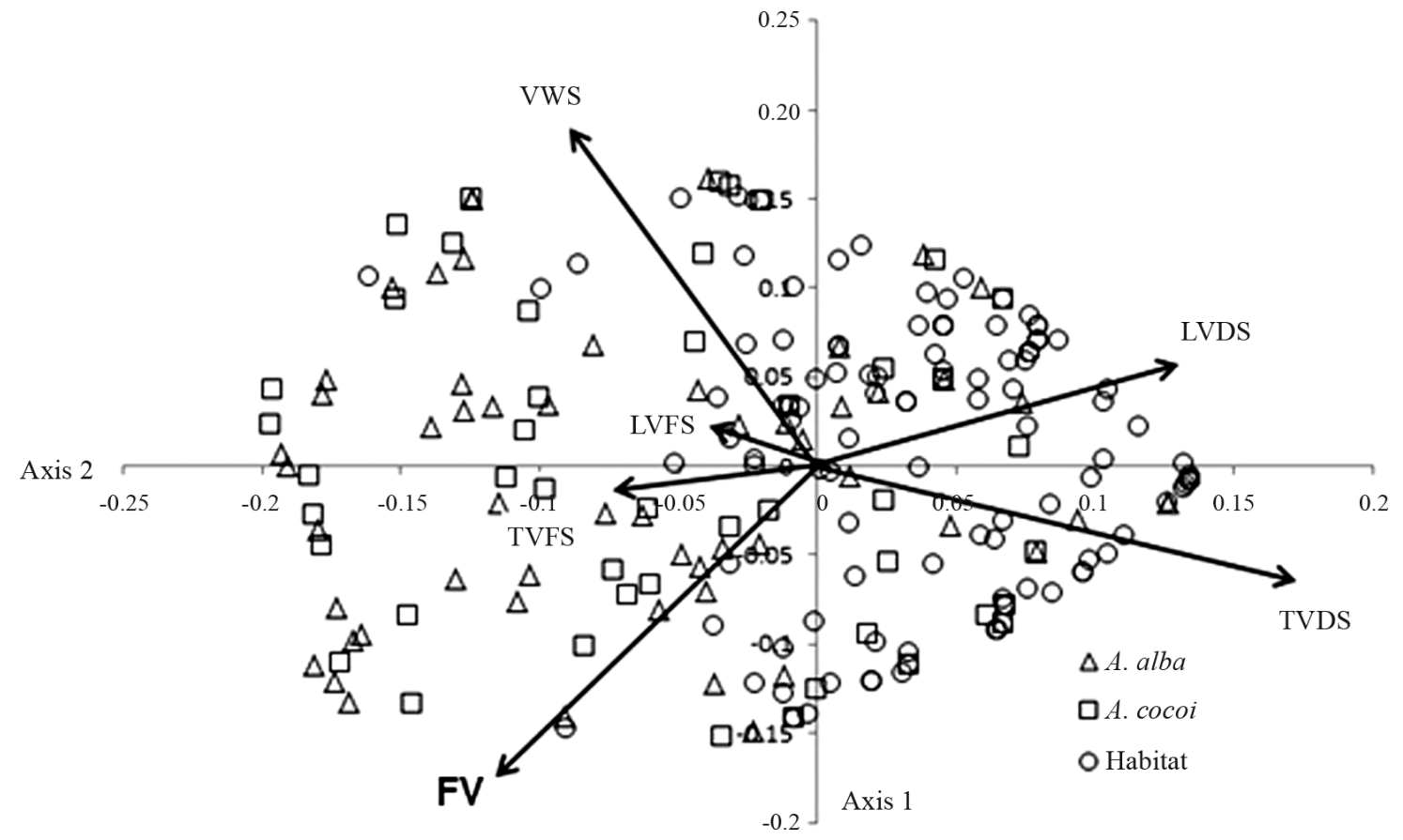

Figure 1 - Ordination diagram ("biplot") of parcels along the $1^{\text {st }}$ and $2^{\text {nd }}$ axes of the Principal Component Analysis (PCA), generated from the analysis of five categories of characteristics of the Taim wetland, including the BR-471 road (arrows). Vectors of category variables of chosen habitats: TVFS $=$ Tall vegetation on flooded substrate, TVDS $=$ Tall vegetation on dry substrate, $\mathrm{LVDS}=$ Low vegetation on dry substrate, $\mathrm{LVFS}=$ Low vegetation on flooded substrate, FV = Floating vegetation, VWS $=$ Visible water surface. The different symbols represent microhabitats used by birds (triangle $=$ Ardea alba; square $=$ Ardea cocoi, circle $=$ available microhabitats) 
its association with cattle (Sick, 1997; Hofling and Camargo, 2002).

In the present study, unlike the expected, fewer individuals of $A$. alba and $A$. coco $i$ were observed on warmer days. Probably during very hot days, egrets seek shelter in more shaded sites that are not available in the study area, since most of the landscape is devoid of trees that could provide shade and cooler areas. We also consider the possibility that higher temperatures might decrease the access to the prey for $A$. alba. Some fishes, including a potential prey of $A$. alba at study site (Rhamdia quelen; Garcia et al., 2006), demonstrate lower levels of mobility during warmer days (Gomes et al., 2000). Despite being a little speculative, we believe that egrets should reduce the foraging activity during hottest days as a consequence to the effect of climatic conditions on their prey (see Stevens, 2002; Bergmann et al., 2013).

The non-interference of the variables examined was expected for B. ibis, as this is a species that feeds in association with cattle (Gasset et al., 2000; Bella and Azevedo-Junior, 2004). This relationship with human activities demonstrates the plasticity of this species (Leitão and Farinha, 1998), which uses a wide variety of habitats (Jenni, 1969; Pemeroy, 1975).

Although no significant differences were found regarding the use of flooded or dry substrates by $A$. alba and A. cocoi, the PCA indicated that both species are associated with habitats with a predominance of flooded areas, especially those with more visible water surface. The low density of shrubs in the microhabitats selected suggests the association of these species with open habitats. In general our findings revealed differences regarding microhabitat use by the three study species, indicating the presence and arrangement of water bodies as important factors for microhabitat selection by native species, although not as evident for $B$. ibis.

Our results support the hypothesis that the structure of habitats determines the structure and composition of assemblages of aquatic birds. Ardea alba and A. cocoi are ecologically similar, including regarding habitat use, as both do not exhibit a microhabitat preference and rarely use perches. Air temperature and air relative humidity are the main environmental variables correlated to the occurrence of these fishing species in the study site.

\section{Acknowledgments}

The authors acknowledge the collaboration of M. S. Gottschalk and G. N. Maurício, the Taim Ecological Station and the logistical support offered from the Universidade Federal de Rio Grande. The study was possible with the financial support of CAPES and CNPq.

\section{References}

ACCORDI, IA., 2003. Estrutura espacial e sazonal da avifauna e considerações sobre a conservação de aves aquáticas em uma área úmida do Rio Grande do Sul, Brasil. Porto Alegre: Universidade Federal do Rio Grande do Sul. Dissertação de Mestrado em Ecologia.
ANTAS, PTZ., 1994. Migration and other movements among the lower Parana river valley wetlands, Argentina, and the south Brazil/Pantanal wetlands. Bird Conser Inter, vol. 4, p. 181-190.

BELLA, SD. and AZEVEDO-JUNIOR, SM., 2004. Considerações sobre a ocorrência da garça-vaqueira, Bubulcus ibis (Linnaeus, 1758) (Aves, Ardeidae), em Pernambuco, Brasil. Rev Bras Zoo, vol. 21, no. 1, p. 57-63.

BELTON, W., 1994. Aves do Rio Grande do Sul: Distribuição e biologia. São Leopoldo: Unisinos. 584 p.

BENCKE, GA., DIAS, RA., BUGONI, L., AGNE, CE., MAURÍCIO, GN. and MACHADO, DB., 2010. Revisão e atualização da lista das aves do Rio Grande do Sul, Brasil. Iheringia, Série Zoologia, vol. 100, no. 4, p. 519-556.

BENNETTS, RE., DARBY, PC. and KARUNARATNE, LB., 2006. Foraging patch selection by Snail Kites in response to vegetation structure and prey abundance and availability. Waterbirds, vol. 29, no. 1, p. 88-94.

BERGMANN, FB., AMARAL, HLC., PINTO, DP., CHIVITTZ, CC. and TOZETTI, AM., 2013. Foraging activity of the snail kite, Rostrhamus sociabilis (Aves: Accipitridae) in wetlands of southern. Brazil. Braz J Biol, in press.

BIBBY, CJ., HILL, DA., BURGUESS, ND. and MUSTOE, S., 2000. Bird Census Techniques. 2nd ed. London: Academic Press. 303 p.

BLOCK, WM. and BRENNAN, LA., 1993. The habitat concept in ornithology: Theory and applications. Plenum Press, New York. Cur Ornith, vol. 11, p. 35-91.

CARVALHO, FF., 2010. Comportamento Alimentar das aves piscívoras aquáticas do parque natural "Chico Mendes". Rev Elet de Biol, vol. 3, no. 2, p. 11-19.

CBRO, 2011. Comite Brasileiro de Registros Ornitológicos. Listas das aves do Brasil. 10th ed. Available from: http://www.cbro.org.br. Acessed in: 15 Jun. 2011.

DARIO, FR., 2010. Avifauna de fragmentos florestais de Mata Atlântica no Sul do Espírito Santo. Biotemas, vol. 23 no. 3, p. 105-115.

DIEGUES, AC., 2002. Povos e águas: inventário de Áreas Úmidas Brasileiras. 2nd ed. Núcleo de apoio à pesquisa sobre populações humanas em áreas úmidas. São Paulo: NUPAUB-USP. 597 p.

FREITAS, SR., CERQUEIRA, R. and VIEIRA, MV., 2002. A device and standard variables to describe microhabitat structure of small mammals based on plant cover. Braz $J$ Biol, vol. 62, no. 4b, p. 795-800.

GARCIA, AM., BEMVENUTI, MA., VIEIRA, JP., MARQUES, DMLM., BURNS, MDM., MORESCO, A. and CONDINI, VL., 2006. Checklist comparison and dominance patterns of the fish fauna at Taim Wetland, South Brazil. Neo Ichth, vol. 4, no. 2, p. 261-268.

GASSET, JW., FOLK, TH., ALEXY, KJ., MILLER, KV., CHAPMAN, BR., BOYD, FL. and HALL, DI., 2000. Food habits of Cattle Egrets on St. Croix, U.S. Virgin Islands. Wilson Bulletin, vol. 112, no. 2, p. 268-271.

GIBBS, JP., 2000. Wetland loss and biodiversity conservation. Conser Biol, vol. 14, no. 1, p. 314-317.

GIMENES, MR. and ANJOS, L., 2011. Quantitative analysis of foraging habitat use by Ciconiiformes in the upper Paraná river floodplain, Brazil. Braz Arch Biol Technol, vol. 54, no. 2, p. 415-427.

GOMES, LC., GOLOMBIESKI, J., CHIPPARI-GOMES, AR. and BALDISSEROTTO, B., 2000. Biologia do Jundiá Rhamdia quelen (Teleostei, Pimelodidae). Santa Maria, Ciência Rural, vol. 30, no. 1, p. 179-185. 
GUADAGNIN, DL. and LAIDNER, C., 1999. Diagnóstico da situação e ações prioritárias para a conservação da zona costeira da Região Sul - Rio Grande do Sul e Santa Catarina. Pronabio, Funbio, Avaliação e ações prioritárias para a conservação da biodiversidade da zona costeira e marinha. Available from: http://www.bdt.org.br/ workshop/costa. Acessed in: 20 Apr. 2011.

HOFLING, E. and CAMARGO, HFA., 2002. Aves no campus. 3rd ed. São Paulo: EDUSP. 176 p.

HUTTO, RL., 1985. Habitat selection by nonbreeding, migratory land birds. In Cody, ML. (ed.). Habitat Selection in Birds. Orlando: Academic Press. P. 455-476.

JENNI, DA., 1969. A study of the ecology of four species of herons during the breeding season at Lake Alice Alachua County, Florida. Durhan, Ecol Monogr, vol. 39, no. 3, p. 245-270.

KOVACH, WL., 1999. MVSP - A Mult-Variate statistical package for Windows, ver. 3.1. Penthraeth: Kovach Computing Services.

LEITÃO, D. and FARINHA, JC., 1998. Método para estimar a área de alimentação em redor de uma colônia de garças. Airo, vol. 9, no. 1/2, p. 9-15.

LOPES, LE. and MARINI, MA., 2006. Home range and habitat use by Suiriri affinis and Suiriri islerorum (Aves: Tyrannidae) in the central Brazilian Cerrado. Studies on Neotropical Fauna and Environment, vol. 41, p. 87-92.

MALUF, JRT., 2000. Nova classificação climática do estado do Rio Grande do Sul. Rev Bras Agrometeorologia, vol. 8, no. 1, p. 141-150.

MALTCHIK, L., BERTOLUCI, VDM. and ERBA, DA., 2003. Inventário das áreas úmidas do município de São Leopoldo, Rio Grande do Sul, Brasil. Pesq Bot, vol. 53, p. 79-88.

MORENO, S., VILLAFUERTE, R., CABEZAS, S. and LOMBARDA, L., 2004. Wild rabbit restocking for predator conservation in Spain. Biol Conserv, 2nd ed., vol. 118, p. 183-193.

MOTTA-JUNIOR, JC., MARCO ANTONIO, MG. and PEDRO, FD., 2008. Aves da Estação Ecológica de Itirapina, estado de São Paulo, Brasil. Biota Neotrop, vol. 8, no. 3, p. 207-227.
NARANJO, LG., 1995. An evaluation of the first inventory of South American wetlands. Vegetatio, vol. 118, no. 1/2, p. $125-129$.

NASCIMENTO, JLX. and SCHULZ-NETO, A., 2000. Aves aquáticas da região do Lago de Sobradinho, Bahia - conservação e potencial de manejo. Melopsittacus, vol. 3, no. 2, p. 53-63.

NUNES, APE. and TOMAS, WM., 2004. Aves migratórias ocorrentes no Pantanal: Caracterização e conservação. Corumbá: Embrapa Pantanal. 27 p. (Documentos 62).

OLIVEIRA, DM., 2006. Efeitos bióticos e abióticos de ambientes alagáveis nas assembleias de aves aquáticas e piscívoras no Pantanal, Brasil.. Manaus: Universidade do Amazonas/Instituto Nacional de Pesquisas da Amazônia. 198 p.Tese de Doutorado.

PEMEROY, DE., 1975. Birds as scavengers of refuse in Uganda. Ibis, vol. 117 , no. 1 , p. 68-81.

POLETTO, F., ANJOS, L., LOPES, EV., VOLTAPATO, GH., SERAFINI, PP. and FAVARO, FL., 2004. Caracterização do microhabitat e vulnerabilidade de cinco espécies de arapaçus (Aves: Dendrocolaptidae) em um fragmento florestal do norte do estado do Paraná, sul do Brasil. Ararajuba, vol. 12, no. 2, p 89-96.

SICK, H., 1997. Ornitologia Brasileira. 1st ed. Rio de Janeiro: Nova Fronteira. 917 p.

STEVENS, AJ., WELCH, ZC., DARBY, PC. and PERCIVAL, HF., 2002. Temperature effects in Florida apple snail activity: implications for snail kite foraging success and distribution. Wildlife Soc B, vol. 30, no. 1, p. 75-81.

WAECHTER, JL., 1985. Aspectos ecológicos da vegetação de restinga no Rio Grande do Sul, Brasil. Comunicações do Museu de Ciências da PUCRS, Sér Bot, vol. 33, p. 49-68.

YOUSEFI, A., BAHMANPOUR, H. and MAFI, A., 2012. Survey of microhabitats use by birds in national parks (Case Study: Wetland Boujagh National Park, Southwest Caspian Sea, Iran). Annals of Biological Research, vol. 3, no. 6, p. 2938-2946.

ZAR, JH., 1999. Biostatistical analysis. Englewood Cliffs: Prentice-Hall. p. 663. 